\title{
Correlation Between Age and Knowledge Among The Student of SMP "X" with The Occurrence of Free Sex
}

\author{
Dani*, Arifani Cahyani, Helena G Manalu, Vanny Angellina \\ *Departement of Public Health \\ **Faculty of Medicine, Maranatha Christian University \\ Jl. Prof. Drg. Suria Sumantri MPH No.65 Bandung 40164 Indonesia \\ Email:dani_fushen@yahoo.co.id
}

\begin{abstract}
Free sex behavior is sexual activity conducted outside of marriage, considered as a social problem for the community and at risk of transmitting the disease. The aim of this study was to determine the relationship between age and knowledge of junior high school students " $X$ " against the occurrence of free sex. This is an analytic observasional study with cross sectional approach. We collected data from 146 respondents aged 11-19 years. Data was analyzed using chi-square statistic test with $\alpha=0,05$. The study was conducted on junior high school students " $X$ " in Purwakarta Regency Indonesia. The results showed that there was a significant correlation between age with the occurrence of free sex $(p=0,000)$, but there was no significant correlation between knowledge $(p=0,250)$ with the occurrence of free sex in junior high school students " $X "$ ". The research shows that as many as $7.54 \%$ of junior high school students " $X$ " claimed to have sexual intercourse. We concluded that there is a correlation between the age of junior high school students " $\mathrm{X}$ " with the occurrence of free sex, but there is no significant relationship between the knowledge of the students SMP " $X^{\prime \prime}$ with the occurrence of free sex.
\end{abstract}

Keywords: knowledge of free sex, free sex, age 


\title{
Hubungan antara Usia dan Pengetahuan Siswa-Siswi SMP "X" dengan Terjadinya Seks Bebas
}

\author{
Dani*, Arifani Cahyani, Helena G Manalu, Vanny Angellina \\ *Bagian Ilmu Kesehatan Masyarakat, Fakultas Kedokteran, Universitas Kristen Maranatha \\ ** Fakultas Kedokteran, Universitas Kristen Maranatha \\ Jl. Prof. Drg. Suria Sumantri MPH No.65 Bandung 40164 Indonesia \\ Email: dani_fushen@yahoo.co.id
}

\begin{abstract}
Abstrak
Perilaku seks bebas adalah aktivitas seksual yang dilakukan di luar pernikahan, dinilai sebagai masalah sosial bagi masyarakat dan berisiko menularkan penyakit. Tujuan penelitian ini adalah untuk mengetahui adanya hubungan usia dan pengetahuan siswa-siswi SMP " $\mathrm{X}$ " terhadap terjadinya seks bebas. Metode penelitian adalah analitik observasional dengan pendekatan cross sectional. Jumlah responden sebanyak 146 responden dengan usia berkisar antara 11-19 tahun. Data dianalisis menggunakan uji statistik chi-square dengan $\alpha=0,05$. Penelitian dilakukan pada siswasiswi SMP "X" di Kabupaten Purwakarta Indonesia. Hasil penelitian menunjukkan terdapat hubungan yang signifikan antara usia dengan terjadinya seks bebas $(p=0,000)$, namun tidak terdapat hubungan yang signifikan antara pengetahuan $(\mathrm{p}=0,250)$ dengan terjadinya seks bebas pada siswa-siswi SMP "X". Penelitian menunjukkan sebanyak 7,54\% siswa-siswi SMP "X" mengaku pernah melakukan hubungan seksual. Simpulan penelitian ini adalah terdapat hubungan antara usia siswa-siswi SMP "X" dengan terjadinya seks bebas, namun tidak terdapat hubungan yang signifikan antara pengetahuan siswa-siswi SMP "X" dengan terjadinya seks bebas.
\end{abstract}

Kata kunci: pengetahuan tentang seks bebas, seks bebas, usia 


\section{Pendahuluan}

Seks bebas merupakan salah satu faktor risiko dari penularan Human Immunodeficiency Virus (HIV). Pada tahun 2013, penderita atau orang yang hidup dengan HIV berjumlah 35 juta di seluruh dunia. HIV dapat berkembang menjadi Acquired Immune Deficiency Syndrome (AIDS) yang memiliki risiko sangat tinggi terkena penyakit infeksi dan berakibat fatal. Pada awal tahun 2009, prevalensi kasus HIV pada penduduk dunia usia 15-49 tahun hanya 0,16\% dan meningkat menjadi 0,30\% tahun 2011. Prevalensi tahun 2012 menjadi 0,32\% dan terus meningkat menjadi 0,43\% tahun $2013 .{ }^{1}$

Hasil kajian statistik 2015 oleh the Joint United Nations Programme on HIV/AIDS (UNAIDS) 2016 menunjukkan terdapat 36,7 juta orang penderita HIV di seluruh dunia, dengan penderita baru HIV sebanyak 2,1 juta orang, dan sebanyak 1,1 juta orang meninggal karena AIDS. Penderita HIV di Asia dan Pasifik pada tahun 2015 tercatat 5,1 juta orang dengan penderita baru HIV sebanyak 300.000 orang, dan 180.000 orang meninggal karena AIDS. ${ }^{1}$

Di Indonesia, HIV/AIDS pertama kali ditemukan di provinsi Bali pada tahun 1987, dan hingga saat ini HIV/AIDS sudah menyebar di 386 kabupaten/kota di seluruh provinsi di Indonesia. Berdasarkan survei , di Indonesia jumlah penderita HIV dari tahun 1987 sebanyak 150.296 orang, sedangkan total penderita AIDS sebanyak 55.799 orang. Jumlah (kumulatif) kasus infeksi HIV yang dilaporkan sejak tahun 1987 di Jawa Barat adalah sebanyak 13.507 kasus. Jumlah kasus di Provinsi Jawa Barat menduduki posisi terbanyak keempat setelah DKI Jakarta yang berjumlah 32.872 kasus, Jawa Timur sebanyak 19.249 kasus dan Papua 16.051 kasus. ${ }^{2}$

Kasus HIV telah dilaporkan oleh dinas kesehatan dari 200 kabupaten dan kota di 33 provinsi di seluruh Indonesia. Jumlah penderita HIV/AIDS pada tahun 2014 meningkat 3 kali lipat dari tahun 2008 (dari 277.800 orang menjadi 813.720 orang) sehingga apabila tidak ada upaya penanggulangan yang bermakna, jumlah ini akan terus meningkat di waktu yang akan datang. ${ }^{1}$

Indonesia dianggap kurang memerhatikan pasien-pasien penderita penyakit HIV/AIDS dan kematian penderita penyakit HIV/AIDS di Indonesia masih tinggi dan kasus HIV/AIDS di Indonesia tiap tahun selalu meningkat. ${ }^{3}$

Penularan HIV/AIDS merupakan konsekuensi akibat dari perilaku seks bebas. Remaja merupakan kelompok usia yang rentan terhadap seks bebas karena pada masa remaja terjadi berbagai perubahan fisik, psikologis, dan intelektual yang sangat pesat. Remaja memiliki rasa ingin 


\section{Research Article}

tahu yang tinggi, menyukai petualangan dan tantangan sehingga cenderung berani menanggung risiko tanpa pertimbangan yang matang. ${ }^{4}$

Menurut data Kemenkes RI tahun 2015, usia 15-17 tahun adalah proporsi terbesar berpacaran pertama kali. Sekitar 33,3\% remaja perempuan dan 34,5\% remaja laki-laki berusia 15-19 tahun telah berpacaran saat usia mereka di bawah 15 tahun. Secara umum, remaja laki-laki lebih banyak yang menyatakan pernah melakukan hubungan seks dibandingkan perempuan. ${ }^{1}$

Kaum remaja yang masih labil ini dikhawatirkan belum memiliki pengetahuan yang cukup sehingga berisiko berperilaku kurang baik, seperti pacaran yang tidak sehat dan melakukan hubungan seks pra nikah. ${ }^{5}$ Remaja perlu diberi pendidikan dan pengetahuan tentang kesehatan reproduksi remaja, khususnya untuk mencegah terjadinya seks bebas dan penularan penyakit menular seksual. Berdasarkan Riskesdas 2013, didapatkan proporsi kehamilan sangat muda (di bawah 15 tahun) di perkotaan adalah $0,02 \%$, sedangkan di pedesaan $0,03 \%$. Proporsi kehamilan pada usia 15-19 tahun adalah 1,97\% dengan proporsi di daerah pedesaan lebih tinggi dari perkotaan.

Penelitian ini dilakukan dengan tujuan untuk mengetahui hubungan usia dan pengetahuan siswa-siswi SMP "X" dengan terjadinya seks bebas.

\section{Metode}

Penelitian ini dilakukan di SMP "X" Kabupaten Purwakarta Indonesia pada 27 November hingga 18 Desember 2017. Metode penelitian bersifat analitik observasional dengan desain cross sectional. Subjek penelitian adalah siswa-siswi kelas 7 hingga 9 SMP "X". Sumber data diperoleh dari hasil kuesioner dan wawancara responden. Variabel terikat pada penelitian ini adalah terjadinya seks bebas (ya dan tidak) sedangkan variabel bebas adalah usia dan pengetahuan responden terhadap seks bebas. Jumlah responden adalah 146 orang. Instrumen pokok penelitian ini adalah kuesioner pilihan ganda. Jumlah pertanyaan dalam kuesioner yang digunakan untuk menilai pengetahuan mengenai seks dalam penelitian ini sebanyak 7 nomor, dan sebanyak 3 pertanyaan mengenai perilaku seks bebas. Data yang didapat diolah menggunakan uji chi-square dengan $\alpha=0,05$.

Penelitian ini telah mendapat persetujuan etik dari dari Komite Etik Penelitian Kedokteran dan Kesehatan, Fakultas Kedokteran, Universitas Kristen Maranatha berdasarkan SK No 238/KEP/X/2017. Seluruh responden yang terlibat dalam penelitian berpartisipasi secara sukarela setelah diberi informasi dan memberikan informed consent sebelum mengisi kuesioner. 


\section{Hasil}

Hasil analisis data usia dan pengetahuan siswa-siswi SMP "X" dan hubungan faktor-faktor tersebut dengan seks bebas tercantum pada tabel 1, 2, dan 3 .

Tabel 1 Distribusi Usia Siswa-siswi SMP "X"

\begin{tabular}{ccc}
\hline Usia (Tahun) & Jumlah (Orang) & Persentase (\%) \\
\hline$<16$ (remaja awal) & 137 & $93,87 \%$ \\
$16-19$ (remaja akhir) & 9 & $6,16 \%$ \\
\hline Total & 146 & $100 \%$ \\
\hline
\end{tabular}

Tabel 2 Analisis Bivariat Usia Siswa-siswi SMP "X" terhadap Terjadinya Seks Bebas

\begin{tabular}{|c|c|c|c|c|c|c|c|}
\hline \multirow[t]{2}{*}{ Usia } & \multicolumn{2}{|c|}{ Seks Bebas } & \multicolumn{2}{|c|}{ Tidak Seks Bebas } & \multirow[t]{2}{*}{ Total } & \multirow[t]{2}{*}{ p Value } & \multirow{2}{*}{$\begin{array}{c}\text { Odds } \\
\text { Ratio }(O R)\end{array}$} \\
\hline & $\mathrm{N}$ & $\%$ & $\mathrm{~N}$ & $\%$ & & & \\
\hline Remaja Awal & 5 & 3,6 & 132 & 96,4 & 137 & $0,000^{*}$ & 0,019 \\
\hline Remaja Akhir & 6 & 66,7 & 3 & 33,3 & 9 & & \\
\hline Total & 11 & & 135 & & 146 & & \\
\hline
\end{tabular}

Keterangan:

remaja awal berusia < 16 tahun, remaja akhir berusia 16-19 tahun.

Jumlah seluruh responden adalah 146 orang, dengan responden yang menyatakan melakukan seks bebas sebanyak 11 orang, dan yang tidak sebanyak 135 orang. Dari hasil analisis bivariat pada tabel 2, didapatkan bahwa terdapat hubungan antara usia dengan terjadinya seks bebas. Hasil uji chi-square menunjukkan nilai $\mathrm{p}=0,000(\mathrm{p}<0,01)$ yang berarti terdapat perbedaan bermakna antara usia remaja awal dan remaja akhir siswa-siswi SMP "X" terhadap terjadinya seks bebas. Persentase pelaku seks bebas pada usia remaja akhir jauh lebih tinggi daripada pada usia remaja awal.

Pengetahuan siswa-siswi SMP "X" dinilai dengan kuesioner dengan pertanyaan-pertanyaan sebagai berikut:

1. Apakah anda mengetahui tentang seks bebas?

2. Jika Ya, seks bebas adalah ...

3. Apakah makna hubungan seksual menurut anda?

4. Apakah hubungan seksual boleh dilakukan sebelum menikah?

5. Hubungan seksual boleh dilakukan atas dasar? 


\section{Research Article}

6. Apakah melakukan seks bebas berisiko menularkan penyakit?

7. Apakah hamil di luar nikah merupakan hal yang memalukan?

Analisis pengetahuan siswa-siswi SMP "X" terhadap terjadinya seks bebas ditampilkan pada tabel 3 .

Tabel 3 Analisis Pengetahuan Siswa-siswi SMP "X" terhadap Terjadinya Seks Bebas

\begin{tabular}{|c|c|c|c|c|c|c|c|}
\hline \multirow[t]{2}{*}{ Pengetahuan } & \multicolumn{2}{|c|}{ Seks Bebas } & \multicolumn{2}{|c|}{ Tidak Seks Bebas } & \multirow[t]{2}{*}{ Total } & \multirow[t]{2}{*}{$p$ Value } & \multirow{2}{*}{$\begin{array}{l}\text { Odds Ratio } \\
\quad(\text { OR })\end{array}$} \\
\hline & $\mathrm{N}$ & $\%$ & $\mathrm{~N}$ & $\%$ & & & \\
\hline Kurang & 3 & 13,0 & 20 & 87,0 & 23 & 0,275 & 2,156 \\
\hline Cukup & 8 & 6,5 & 115 & 93,5 & 123 & & \\
\hline Total & 11 & & 135 & & 146 & & \\
\hline
\end{tabular}

Dari hasil analisis bivariat pada tabel 3, didapatkan bahwa tidak terdapat hubungan antara pengetahuan terhadap terjadinya seks bebas $(\mathrm{p}=0,275)$.

Sebanyak 11 orang siswa-siswi (7,54\%) mengaku pernah melakukan hubungan seksual. Siswa-siswi tersebut mendapatkan pertanyaan lanjutan, sebagai berikut:

1. Jika pernah melakukan hubungan seks, dimana anda melakukannya? Yang menjawab di sekolah $9,1 \%$, di rumah $36,4 \%$, di hotel $54,5 \%$.

2. Jika pernah melakukan hubungan seks, berapa kali anda sudah melakukannya? Yang menjawab 1 kali 18,2\%, yang menjawab 3 kali 9,1\%, yang menjawab 4 kali 36,4\%, yang menjawab > 4 kali $27,3 \%$, yang tidak menjawab $9.1 \%$.

3. Jika pernah melakukan hubungan seks, apa alat kontrasepsi yang anda gunakan? Yang menjawab mennggunakan kondom 90,9\% dan yang menggunakan spiral 9,1\%.

\section{Diskusi}

Hurlock (1990) membagi masa remaja menjadi dua, yaitu masa remaja awal ( $<16$ tahun) dan remaja akhir (16-19 tahun). Pada masa remaja akhir, individu sudah mencapai transisi perkembangan yang lebih mendekati masa dewasa. ${ }^{6}$

Perilaku seksual pranikah adalah kegiatan seksual yang melibatkan dua orang yang saling menyukai atau saling mencintai, yang dilakukan sebelum perkawinan. ${ }^{3}$ Perilaku seksual pranikah disebut juga seks bebas. Seks bebas adalah segala tingkah laku yang didorong oleh hasrat seksual 


\section{Research Article}

terhadap lawan jenisnya, melalui perbuatan yang tercermin dalam perilaku seksual, dari tahap yang paling ringan hingga tahap paling berat yang dilakukan sebelum pernikahan yang resmi menurut hukum maupun agama. ${ }^{7}$

Pengetahuan para remaja tentang perilaku seksual yang benar sangat kurang karena umumnya remaja hanya mendapat pengetahuan dari pembicaraan dengan teman, video, atau film porno. Perilaku seksual pranikah atau pergaulan seks bebas di kalangan remaja Indonesia saat ini memang sangatlah memprihatinkan. Berdasarkan data dari Komisi Perlindungan Anak Indonesia (KPAI), sebanyak 32 persen remaja usia 14 hingga 18 tahun di kota-kota besar di Indonesia (Jakarta, Surabaya, dan Bandung) pernah melakukan hubungan seks pranikah. ${ }^{1}$ Hasil survei BKKBN menyatakan, satu dari empat remaja Indonesia melakukan hubungan seksual pranikah dan 62,7 persen remaja putri kehilangan keperawanan saat masih duduk di bangku SMP. Penelitian yang telah dilakukan terhadap 146 orang siswa-siswi, proporsi terbesar berusia 13-15 tahun, yaitu sebanyak 78,77\%. Hasil survei BKKBN menyebutkan bahwa karakteristik umur potensial yang rawan tertular HIV/AIDS adalah kelompok remaja yatu 31\%; terdiri atas $7 \%$ berumur di bawah 20 tahun dan $24 \%$ berumur antara 20-24 tahun. ${ }^{3}$

Remaja berusia 13-15 tahun berada pada tahap sangat membutuhkan kawan-kawan, senang apabila ia memiliki banyak teman, terlebih jika memiliki sifat yang sama. Selain itu, pada tahap ini remaja mengalami kebingungan (krisis identitas) karena ia tidak tahu harus memilih teman seperti apa, sedangkan pergaulan sangat berpengaruh terhadap perilaku. Teman yang memiliki perilaku yang buruk akan membawa remaja berperilaku buruk pula terutama dalam hal perilaku seksual. Secara seksual remaja dalam tahap ini mulai mengalami perkembangan fisik dan seksual, juga mulai memilki keberanian untuk melakukan kontak fisik dengan lawan jenis. ${ }^{8}$ Gaya berpacaran remaja tahap ini sudah mulai berpegangan tangan, berpelukan, meraba bagian tubuh lawan jenis bahkan hingga berhubungan dengan organ kelamin. ${ }^{4}$

Hasil penelitian menunjukkan terdapat 7,54\% siswa-siswi SMP "X" yang mengaku pernah melakukan hubungan seksual pranikah, berarti masih terdapat masalah perilaku seks yang perlu diperbaiki di kalangan para remaja. Hasil penelitian menunjukkan bahwa terdapat hubungan antara usia dengan terjadinya seks bebas pada siswa-siswi SMP "X" dengan nilai $p=0,000(p<0,01)$. Dalam penelitian ini, jumlah responden seks bebas lebih banyak pada usia remaja akhir. Hal ini terjadi diduga karena pada usia remaja akhir perkembangan fisik dan hormonal sudah lebih matang, diikuti oleh rasa ingin tahu yang besar, selain itu diperparah oleh informasi dan risiko mengenai seks 


\section{Research Article}

bebas yang tidak sepenuhnya dipahami sehingga menyebabkan remaja tahap ini melakukan cobacoba untuk mendapat pengalaman melakukan seks bebas (trial and error).

Penyuluhan atau edukasi dini oleh guru atau tenaga kesehatan mengenai kesehatan reproduksi sangat dibutuhkan demikian juga akibat dan risiko seks bebas untuk anak yang menginjak masa remaja. Dengan semakin meningkatnya kasus seks bebas pada penduduk usia muda, penyebaran informasi untuk meningkatkan public awareness mengenai bahaya seks bebas nampaknya tidak dapat ditunda lagi. ${ }^{9}$ Selama ini kelompok usia muda tersebut masih kurang mendapat perhatian dari pihak-pihak yang bertanggungjawab terhadap penanggulangan kehamilan yang tidak diinginkan, penyakit menular seksual, dan HIV/AIDS.

Hasil penelitian mengenai pengetahuan siswa-siswi SMP "X" menunjukkan sebanyak 123 responden $(84,25 \%)$ memiliki pengetahuan yang cukup mengenai seks bebas, sedangkan 23 responden lainnya $(15,75 \%)$ memiliki pengetahuan yang kurang. Akan tetapi, secara statistik, tidak terdapat hubungan antara pengetahuan siswa-siswi SMP " $\mathrm{X}$ " dengan terjadinya seks bebas $(\mathrm{p}=0,275)$. Masyarakat Indonesia masih banyak yang kurang memiliki pengetahuan tentang kesehatan reproduksi pribadi dan bahaya dari seks bebas. Terdapat beberapa faktor yang mempengaruhi pengetahuan seseorang yaitu faktor internal (pendidikan, motivasi, dan persepsi) serta faktor eksternal (informasi, sosial, budaya, dan lingkungan). ${ }^{10}$ Pentingnya remaja memiliki pengetahuan mengenai masalah seksual atau kesehatan reproduksi terutama agar remaja memiliki informasi yang benar mengenai masalah seksual atau kesehatan reproduksi. Pemerintah Indonesia melalui Departemen Pendidikan bekerjasama dengan Departemen Kesehatan, perlu mengadakan pendekatan yang lebih terfokus pada kelompok-kelompok ini. Penyuluhan tentang seks bebas dan bahayanya dapat dilakukan dengan penyebaran leaflet-leaflet dalam bahasa yang komunikatif di tempat yang biasa dipakai untuk para remaja berkumpul atau juga lewat sekolah-sekolah menengah. Sebaliknya, arus informasi yang negatif mengenai pengetahuan dan perilaku seksual perlu dicegah karena akan berdampak pada perilaku yang negatif pula. ${ }^{11}$

Hasil penelitian mengenai perilaku siswa-siswi SMP "X" terhadap seks bebas menunjukkan bahwa terdapat 7,54\% siswa-siswi SMP "X" yang mengaku melakukan hubungan seksual. Hal ini menunjukkan bahwa jika informasi yang didapat seorang remaja salah atau kurang tepat maka perilaku remaja pun akan kurang tepat bahkan salah dan dapat berisiko menyebabkan penyimpangan perilaku seksual terutama dalam hal seks bebas. Teman sebaya, media massa, hubungan keluarga yang harmonis merupakan faktor penting yang sangat mempengaruhi sikap remaja terhadap perilaku seksual. Komunikasi yang baik dan terbuka antara orang tua dan anak 


\section{Research Article}

sangat diperlukan, sehingga dapat menghindarkan anak dari rasa sungkan (malu) menceritakan atau menanyakan apapun pada orang tua. Komunikasi yang baik dapat mencegah anak (khususnya remaja) dari perbuatan yang melanggar norma. ${ }^{12}$ Kedekatan dengan kedua orangtua merupakan hal positif yang terbukti berpengaruh baik terhadap perilaku remaja. Remaja sebaiknya terbuka pada kedua orangtuanya tentang segala masalah yang dialaminya sehingga ia memperoleh informasi yang benar dari kedua orangtua mereka tentang perilaku yang benar dan moral yang baik dalam menjalani kehidupan serta mengetahui hal-hal yang perlu dilakukan dan yang perlu dihindari. Untuk menurunkan angka kejadian seks bebas dengan segala konsekuensinya, perlu kesiapan dari pemerintah, sekolah, orang tua, dan aparat pelayanan kesehatan guna memberikan pelayanan pengetahuan kesehatan reproduksi dan seks yang baik bagi kelompok remaja.

\section{Simpulan}

Berdasarkan hasil penelitian yang dilakukan pada siswa-siswi SMP "X" disimpulkan bahwa terdapat hubungan antara usia responden responden terhadap terjadinya seks bebas di SMP "X", namun tidak terdapat hubungan antara pengetahuan responden dengan seks bebas di SMP "X".

\section{Saran}

Berdasarkan hasil penelitian ini, maka dapat disarankan beberapa hal, yaitu:

- Perlu penelitian lebih lanjut mengenai faktor-faktor lain yang dapat memengaruhi terjadinya seks bebas di kalangan remaja.

- Perlu dukungan lintas sektoral antara pemerintah, departemen terkait, sekolah dan orang tua untuk turut berperan dalam meningkatkan pengetahuan dan sikap remaja yang tepat terhadap perilaku seksual.

- Tenaga kesehatan perlu bekerjasama dengan pihak sekolah untuk memberikan edukasi mengenai kesehatan reproduksi remaja, dalam hal ini khususnya mengenai seks bebas dan bahaya yang dapat ditimbulkan.

\section{Daftar Pustaka}

1. Kemenkes RI. Infodatin: Situasi dan Analisis HIV AIDS. 2014 [Cited 2017 November 23]; Available from: http://www.depkes.go.id/resources/download/pusdatin/infodatin/Infodatin\%20AIDS.

2. Purwaningsih S, Widayatun S. Perkembangan HIV Dan AIDS di Indonesia Tinjauan Sosio Demografis. Jurnal Kependudukan Indonesia. 2008;3(2): 79-95.

3. Fuad AA. Makna Hubungan Seks Bagi Remaja yang Belum Menikah di Kota Surabaya. Jurnal Sosial dan Politik Departemen Sosiologi. Universitas Airlangga. 2015;3(2): 14-7. 


\section{Research Article}

3. Dika YA, Andik M. Pola Asuh Otoriter, Kontrol Diri dan Perilaku Seks Bebas Remaja SMK; Persona, Jurnal Psikologi Indonesia. 2013;2(2):173-82.

4. Yusnaini. 'Keteguhan Jiwa dengan Landasan Keimanan sebagai Pondasi Menengah Perbuatan Amoral'. Jurnal Penelitian Andalas. 2002;14(39):1-9.

5. Winer RL. Hughes Feng Q. Condoms Use and Risk og Genital Human Papiloma Virus Infection in Young Woman. New Eng J Med. 2006;354:2645-54.

6. Kemenkes RI. Kesehatan Reproduksi dan Seksual Bagi Calon Pengantin. 2015. [Cited 2017 December 13]; Available from: http://kesga.kemkes.go.id/images/pedoman/BUKU\%20SAKU\%20KESPRO.

7. Anna S. Perilaku Seks Pranikah Di Kalangan Remaja.; Studi Deskriptif Kualitatif Tentang Perilaku Seks Pranikah Di Kalangan Remaja Kota Surakarta. 2010. Fakultas Ilmu Sosial dan Ilmu Politik. Universitas Sebelas Maret Surakarta. Repository.

8. Sarwono SW. Psikologi Remaja. Jakarta: PT. Raja Grafindo Persada; 2011.

9. Abidinsyah S. Kebijakan Program Kependudukan, Keluarga Berencana, dan Pembangunan Keluarga dalam Mendukung Keluarga Sehat. 2016 [Cited 2017 December 13]; Available from: https://www.bkkbn.go.id2002.

10. Silvia. Netralisasi Perilaku Seks Bebas (one night stand) pada Perempuan Dewasa Muda. Jurnal Kriminologi Indonesia. 2009;2(2):9-18.

11. Farida. Pergaulan Bebas dan Hamil Pranikah. Jurnal Analisa.2009;16(1):125-35. 